\title{
Metode Resitasi dalam Pembelajaran Pendidikan Agama Islam
}

\author{
SYAHRAINI TAMBAK \\ Fakultas Agama Islam (FAI) Universitas Islam Riau (UIR) Pekanbaru \\ Jl. Kaharuddin Nasution, No. 113, Perhentian Marpoyan Pekanbaru 28284 \\ e-mail: syahraini tambak@yahoo.co.id
}

\begin{abstract}
Abstrak: Dalam proses belajar mengajar, guru berperan penting dalam peningkatan mutu pendidikan. Untuk menghasilkan pendidikan yang efektif dan efisien, diperlukan metode mengajar yang sesuai. Penerapan suatu metode dalam pengajaran harus ditinjau dari segi keefektifan, keefesienan dan kecocokannya dengan karakteristik materi pelajaran serta keadaan peserta didik yang meliputi kemampuan, kecepatan belajar, minat, waktu yang dimiliki dan keadaan sosial ekonomi peserta didik. Selain itu, pembelajaran dengan metode mengajar yang sesuai dengan materi yang diajarkan dipercaya meningkatkan motivasi belajar peserta didik. Metode resitasi merupakan metode dimana guru memberikan tugas tertentu agar peserta didik melakukan kegiatan belajar. Dalam pembelajaran PAI (pendidikan agama islam), proses belajar peserta didik secara maksimal dapat di hasilkan melalui metode resitasi yang mana metode ini dapat dilaksanan baik di dalam maupun di luar kelas dan selama itu berada dalam lingkungan sekolah. Alasan penggunaan metode resitasi dalam pelajaran PAI adalah karena bahan pelajaran yang ada dirasakan terlalu banyak, sementara waktu yang tersedia hany sedikit. Artinya, banyaknya bahan yang tersedia dengan waktukurang seimbang. Dengan demikian, agar bahan pelajaran selesai sesuai batas waktu yang di tentukan, maka metode resitasi inilah salah satu metode yang dapat digunakan oleh para guru PAI untuk.
\end{abstract}

\section{PENDAHULUAN}

Peningkatan mutu pendidikan sangat ditentukan oleh guru sebagai pendidik dalam pencapaian tujuan pendidikan yang diharapkan. Dengan kata lain guru menempati titik sentral pendidikan. Agar guru mampu menunaikan tugasnya dengan baik, maka terlebih dahulu harus memahami hal-hal yang berhubungan dengan proses belajar mengajar seperti halnya proses pendidikan pada umumnya. Dengan demikian peranan guru yang sangat penting adalah mengaktifkan dan mengefisienkan proses belajar di sekolah termasuk di dalamnya penggunaan metode mengajar yang sesuai.

Penggunaan metode mengajar yang tepat, merupakan suatu alternatif mengatasi masalah rendahnya daya serap peserta didik terhadap pelajaran, guna meningkatkan mutu pengajaran. Penerapan suatu metode pengajaran harus ditinjau dari segi keefektifan, keefesienan dan kecocokannya dengan karakteristik materi pelajaran serta keadaan peserta didik yang meliputi kemampuan, kecepatan belajar, minat, waktu yang dimiliki dan keadaan sosial 
ekonomi peserta didik sebagai obyek. Sesuai yang dikatakan oleh Rostiyah bahwa "setiap jenis metode pengajaran harus sesuai atau tepat untuk mencapai suatu tujuan tertentu. Jadi untuk tujuan yang berbeda guru harus mengadakan teknik penyajian yang berbeda sekaligus untuk mencapai tujuan pengajarannya" (Rostiyah, 1989: 1).

Salah satu metode yang diterapkan dalam melibatkan peserta didik secara aktif, guna menunjang kelancaran proses belajar mengajar adalah menggunakan metode resitasi (Sudjana, 1989: 1). Dalam metode resitasi diharapkan mampu memancing keaktifan peserta didik dalam proses belajarn mengajar. Hal ini disebabkan karena peserta didik dituntut untuk menyelesaikan tugas yang diberikan guru dan harus dipertanggungjawabkan (Sudjana, 1989: 82). Dalam keberhasilan proses belajar mengajar di samping tugas guru, maka peserta didik turut memegang peranan yang menentukan dalam pencapaian tujuan pendidikan. Sebab bagaimapun baiknya penyajian guru terhadap materi pelajaran, akan tetapi peserta didik tidak mempunyai perhatian dalam hal belajar maka apa yang diharapkan sukar tercapai. Menurut Slameto "agar peserta didik berhasil dalam belajarnya, perlulah mengerjakan tugas dengan sebaikbaiknya. Tugas itu mencakup mengerjakan PR, menjawab soal latihan buatan sendiri, soal dalam buku pegangan, tes/ualangan harian, ulangan umum dan ujian" (Slameto, 1991: 88).

Pembelajaran dengan metode mengajar yang sesuai dengan materi yang diajarkan akan meningkatkan motivasi belajar peserta didik. Sebagai contoh adalah pemberian tugas pada setiap akhir pelajaran dengan harapan aktifitas belajar peserta didik dapat ditingkatkan, sehingga prestasi belajar peserta didik dapat pula meningkat.
Menurut Harmawati "pemberian tugas pada setiap pertemuan mempengaruhi hasil belajar peserta didik. Dengan demikian tugas setiap pertemuan menyebabkan peserta didik termotivasi dalam belajar, disamping itu peserta didik lebih aktif dalam kegiatan belajar mengajar" (Harmawati, 1993: 38).

Pada peningkatan prestasi belajar peserta didik bukan hanya peran guru yang dibutuhkan tetapi peserta didik sendirilah yang dituntut peran aktif dalam proses belajar mengajar. Salah satu hal yang penting dimiliki oleh peserta didik dalam meningkatkan prestasi belajarnya adalah penguasaan bahan pelajaran. Peserta didik yang kurang mengusai bahan pelajaran akan mempunyai nilai yang lebih rendah bila dibandingkan dengan peserta didik yang lebih mengusai bahan pelajaran. Untuk menguasai bahan pelajaran maka dituntut adanya aktifitas dari peserta didik yang bukan hanya sekedar mengingat, tetapi lebih dari itu yakni memahami, mengaplikasikan, mensistesis, dan mengevaluasi bahan pelajaran.

Perlu disadari bahwa yang diharapkan oleh guru terhadap peserta didiknya adalah bahan pelajaran yang diterima peserta didik dapat dikuasainya dengan baik. Olehnya itu, maka salah satu cara yang ditempuh adalah tugas yang diberikan oleh guru tidak hanya dikerjakan di kelas yang sempit dan terbatas oleh waktu, akan tetapi perlu dilanjutkan di rumah, di perpustakaan, di laboratorium dan hasilnya harus dipertanggungjawabkan.

\section{PENGERTIAN METODE RESITASI}

Metode resitasi menurut Syah (2006: 148) adalah penyajian bahan pelajaran dengan memberikan tugas tertentu kepada peserta didik yang dapat dilakukan di dalam dan di luar 
kelas, di laboratorium, di perpustakaan, di bengkel atau di rumah. Berdasarkan pendapat ini dapat dikatakan bahwa metode resitasi dalam istilah Indonesia merupakan penugasan yaitu metode penyajian bahan dimana guru memberikan tugas tertentu agar peserta didik melakukan kegiatan belajar. Penekanannya metode ini adalah adanya tugas belajar yang diberikan oleh guru PAI dalam mencapai proses belajar peserta didik secara maksimal di dalam di luar kelas dan selama itu berada dalam lingkungan sekolah (Sardiman, 1987: 28). Tugas yang dilaksanakan oleh peserta didik dapat dilakukan di dalam kelas, di halaman sekolah, di laboratorium, di perpustakaan, di bengkel, dan selama itu berada di lingkungan sekolah.

Bila melihat pada proses pelaksanaan pembelajaran PAI yang sesungguhnya di dalam kelas, maka pengertian metode resitasi yang dikemukakan Darwyan Syah, et. al., di atas sangat tepat untuk menggambarkan bagian-bagian penting dalam proses pembalajaran peserta didik. Hal ini dikemukakan karena proses pembelajaran yang dilaksanakan guru haruslah dapat diawasi dengan baik dan itu bermula dari kelas. Pembelajaran yang dilaksanakan oleh peserta didik dapat diawasi secara langsung oleh guru PAI sehingga dapat memberikan dorongan dan motivasi terhadap peserta didik yang sedang melaksanakan tugas tersebut. Guru PAI tetap dapat memberikan kontrol terhadap semua peserta didik yang mengerjakan tugas yang dibatasi dengan waktu tertentu. Oleh karena itu, dari pendapat ini dapat diinterpretasi bahwa metode resitasi tidaklah dilaksanakan di luar jam pelajaran akan tetapi masih dalam lingkup waktu pelajaran tersebut.

Pendapat yang agak berbeda dengan di atas dapat dilihat pada dua tokoh berikut. Imansjah Alipandie dalam bukunya berjudul "Didaktik Metodik Pendidikan Umum" mengemukakan bahwa metode resitasi adalah cara untuk mengajar yang dilakukan dengan jalan memberi tugas khusus kepada peserta didik untuk mengerjakan sesuatu di luar jam pelajaran. Pelaksanaannya bisa di rumah, di perpustakaan, di laboratorium, dan hasil belajarnya dapat dipertanggungjawabkan (Alipandie, 1984: 91). Pendapat ini menggambarkan bahwa metode resitasi tersebut menekankan pada mengajar melalui pemberian tugas khusus pada peserta didik untuk dikerjakan di luar jam pelajaran. Bila hal ini dikaitkan dengan pembelajaran PAI maka tampaknya metode resitasi ini dilangsungkan tidak dalam pembelajaran formal di kelas tapi di luar kelas dan tugas-tugas tersebut harus dipertangggungjawabkan.

Sedangkan

Slameto mengemukakan metode resitasi adalah cara penyampaian bahan pelajaran dengan memberikan tugas kepada peserta didik untuk dikerjakan di luar jadwal sekolah dalam rentangan waktu tertentu dan hasilnya harus dipertanggungjawabkan kepada guru (Slameto, 1991: 115). Pendapat Slameto ini memiliki kemiripan dengan pendapat sebelumnya seperti apa yang diungkapkan Alipandi di atas. Di sini Slameto menggambarkan bahwa metode resitasi menekankan pada cara penyampaian bahan pelajaran melalui tugas yang dikerjakan peserta didik di luar kelas.

Dua pendapat di atas dapat diinterpretasi bahwa metode resitasi adalah pemberian tugas kepada peserta didik di luar jadwal sekolah atau diluar jadwal pelajaran yang pada akhirnya dipertanggungjawabkan kepada guru yang bersangkutan. Metode resitasi merupakan salah satu pilihan metode 
mengajar seorang guru, dimana guru memberikan sejumlah item tes kepada peserta didiknya untuk dikerjakan di luar jam pelajaran. Pemberian item tes ini biasanya dilakukan pada setiap kegiatan belajar mengajar di kelas, pada akhir setiap pertemuan atau akhir pertemuan di kelas.

Pemberian tugas ini, menurut Imansyah Alipandi, merupakan salah satu alternatif untuk lebih menyempurnakan penyampaian tujuan pembelajaran khusus. Hal ini disebabkan oleh padatnya materi pelajaran yang harus disampaikan sementara waktu belajar sangat terbatas di dalam kelas. Dengan banyaknya kegiatan pendidikan di sekolah dalam usaha meningkatkan mutu dan frekuensi isi pelajaran, maka sangat menyita waktu peserta didik utnuk melaksanakan kegiatan belajar mengajar tersebut. Maka untuk mengatasi keadaan seperti di atas, guru perlu memberikan tugas-tugas diluar jam pelajaran. Tugas tersebut dapat berbentuk pemberian tugas-tugas berupa PR mempunyai pengaruh yang positif terhadap peningkatan prestasi belajar PAI. Metode resitasi adalah metode penyajian bahan dimana guru memberikan tugas tertentu agar peserta didik melakukan kegiatan belajar. Metode ini diberikan karena dirasakan bahan pelajaran terlalu banyak sementara waktu sedikit. Tugas tidak sama dengan pekerjaan rumah (PR), tetapi jauh lebih luas (Alipandie, 1984: 94).

Menurut hemat penulis, metode resitasi tersebut bukanlah dilakukan karena kebanyakan materi pembelajaran di sekolah hingga memerlukan pelaksanaannya di luar jam pelajaran. Akan tetapi metode ini dilaksanakan harus sesuai dengan indikator pembelajaran PAI yang telah ditetapkan dalam silabus guru PAI.
Apabila metode resitasi ini dilaksanakan karena kebanyakan materi pembelajaran di sekolah, ini menunjukkan kelemahan guru dalam memenej materi yang akan disampaikan.

Maka penerapan metode ini dalam pembelajaran PAI bukanlah terjadi di luar kelas saja, akan tetapi hal ini bisa dilakukan di dalam kelas di mana guru masih dapat melakukan pengawasan pada setiap aktivitas pembelajaran peserta didik. Materi yang diajarkan guru PAI dalam pembelajaran tidaklah dibuat dalam berbentuk tes-tes seperti halnya tes dalam ujian akan tetapi tugas yang dapat menghantarkan peserta didik untuk pemahaman dan penguasaan terhadap materi yang sesuai dengan indikator pembelajaran. Maka guru PAI haruslah betul-betul memahami karakteristik materi PAI yang akan diajarkan melalui metode resitasi.

Maka menurut hemat penulis metode resitasi dalam pendidikan agama Islam adalah penyajian bahan pelajaran PAI dengan memberikan tugas tertentu sesuai dengan indikator pembelajaran oleh guru PAI kepada peserta didik, dilakukan di dalam dan di luar kelas dalam lingkup lingkungan sekolah dan hasilnya dapat dipertanggungjawabkan peserta didik untuk mencapai tujuan pembelajaran. Pengertian metode resitasi dalam pembelajaran PAI ini mengandung lima komponen penting yang dapat dijelaskan untuk mempertegas makna metode resitasi itu sendiri.

Pertama, adanya penyajian bahan pelajaran PAI. Penyajian bahan pelajaran dimaknai bahwa guru PAI menyajikan bahan-bahan pelajaran yang telah dirumuskan dalam indikator pembelajaran kepada peserta didik. Penyajian bahan-bahan pelajaran ini tentu dilakukan oleh guru PAI di dalam 
kelas di mana peserta didik mengikutinya tetap sesuai dengan jadwal pembelajaran. Di sini guru PAI harus dapat memberikan analisis terhadap karakteristik materi pelajaran PAI yang sesuai dengan indikator pembelajaran untuk dapat diajarkan dengan metode resitasi. Hal ini menggambarkan bahwa tugas yang diberikan kepada peserta didik tidaklah lepas dari suasana kelas dan guru PAI harus menyajikan materi PAI.

Kedua, adanya pemberian tugas dari guru PAI kepada peserta didik. Tugas yang diberikan guru PAI kepada peserta didik dianalisis dari indikator pembelajaran PAI yang telah ditetapkan sebelumnya. Tugas ini bisa saja pengembangan dari indikator pembelajaran PAI untuk memperkaya wawasan pengembangan pengetahuan peserta didik. Atau bisa saja langsung pada indikator yang ada karena memang dianggap hal itu membutuhkan tugas langsung karena cakupannya sangat luas dan membutuhkan kemampuan analisis. Pemberian tugas ini dapat saja dilakukan secara individu atau kelompok. Tugas yang dikerjakan berkelompok merupakan materi yang luas yang menuntut kerjasama dalam tim. Tugas yang dilakukan secara individu merupakan tugas yang menuntut analisis masing-masing dan cakupannya hanya pada satu proses penyelesaian saja. Tugas yang diberikan pada peserta didik juga dapat berupa hal yang sama dimana guru PAI menuntut peserta didik untuk melakukan analisis masing-masing. Tapi juga tugas tersebut dapat saja diberikan dengan hal yang berbeda antara satu orang atau kelompok dengan lainnya sebagai maksud untuk memperkaya pengetahuan peserta didik tentang indikator yang sedang dipelajari.

Di sinilah seorang guru PAI harus menjelaskan secara detail tugas demi tugas yang akan dikerjakan oleh para peserta didiknya. Prosedur pelaksanaan tugas harus dijelaskan secara gamblang oleh guru PAI hingga para peserta didik benar-benar dapat memahami alur dan prosedur tersebut. Berapa lama waktu yang dibutuhkan untuk menyelesaikan tugas tersebut harus ditetapkan oleh guru PAI agar peserta didik dapat memenej diri hingga tidak kebablasan menghabiskan waktu dalam pelaksanaannya.

Ketiga, dilakukan di dalam di luar kelas dalam lingkup lingkungan sekolah. Hal terpenting untuk dipahami oleh guru PAI juga adalah bahwa metode resitasi dapat dilakukan di dalam kelas dan dan juga di luar kelas dan selama itu berada dalam lingkup sekolah. Pemahaman terhadap hal ini perlu dikemukakan untuk menjelaskan pengertian metode ini karena ada sebahagian pendapat bahwa metode resitasi dilaksanakan di luar jam belajar.

Tugas yang diberikan untuk dikerjakan di dalam kelas bisa saja dilakukan sebagai bentuk penyelesaian terhadap indikator pembelajaran atau pengembangan dari indikator pembelajaran tersebut. Tentu tugas yang seperti ini yang menuntut analisis tajam dari seluruh peserta didik serta pengembangan kemampuan peserta didik. Sementara tugas di luar kelas dapat dikerjakan diberbagai tempat seperti di perpustakaan, laboratorium, dan lingkungan sekolah lainnya. Tugas yang dilakukan di luar kelas bisa saja tugas yang menuntut pengembangan diri seperti observasi, wawancara, dan lainnya di mana sumber belajarnya tidak ditemukan di dalam kelas. Inilah yang membedakan pemberian tugas di dalam kelas atau di luar kelas adalah terletak pada sumber belajar yang dimiliki.

Keempat, hasil tugas dapat dipertanggungjawabkan peserta didik. 
Tugas yang telah selesai dikerjakan oleh peserta didik harus dipertanggungjawabkan di dalam kelas. Pertanggungjawaban ini merupakan laporan yang harus dipresentasikan oleh para peserta didik kepada peserta didik lainnya di dalam kelas. Maka sebelum peserta didik membertanggungjawabkan, haruslah disusun laporan tersebut sedemikian rupa sesuai prosedur yang telah ditetapkan hingga pada saat presentasi dapat secara tepat dilakukan. Perlu ditegaskan di sini bahwa tugas yang dipertanggungjawabkan tersebut haruslah dipresentasikan tidak bisa hanya sekedar laporan saja. Hal ini dilakukan karena bila hanya laporan saja tanpa dipresentasikan maka peserta didik yang lainnya tidak akan mengetahui apa hasil yang ditemukan peserta didik lainnya dan wawasan pengetahuan peserta didik pun berkurang. Sementara tugas tersebut sesuai dengan indikator pembelajaran, maka secara otomatis tugas yang telah diselesaikan harus diketahui oleh semua peserta didik.

$$
\text { Maka pertanggungjawaban }
$$

tersebut mau tidak mau haruslah berupa presentasi masing-masing individu atau kelompok terhadap hasil yang berhasil ditemukan. Presentasi tugas tersebut haruslah pula dibatasi waktunya oleh guru PAI hingga semua peserta didik mendapatkan giliran yang sama. Hal ini dilakukan sebagai bentuk tanggug jawab peserta didik juga terhadap apa yang dilakukan sebagai hasil dari tugas dan sekaligus untuk membina karakter tangguh, berani dan jujur.

Kelima, adanya pencapaian tujuan pembelajaran. Semua tugas yang dilakukan oleh peserta didik haruslah mengarah para proses tercapainya tujuan pembelajaran yang telah ditetapkan. Maka disaat para peserta didik memberikan pertanggungjawaban haruslah diperhatikan oleh guru apakah tugas tersebut telah sesuai dengan tujuan yang diharapkan. Semua peserta didik dalam proses penyelesaian tugas harus memperhatikan tujuan pembelajaran yang akan dicapai. Pencapaian tujuan ini merupakan panduan para peserta didik dalam pelaksanaan tugas-tugasnya hingga mereka dapat memetik hasil baik untuk dipahami dan diamalkan.

\section{DASAR METODE RESITASI}

Metode resitasi atau pemberian tugas yang menekankan pada interaksi belajar mengajar yang ditandai dengan adanya tugas dari guru PAI yang dikerjakan oleh peserta didik di dalam kelas maupun di luar kelas dalam lingkup sekolah dan bukan dikerjakan di rumah (Mulyani \& Permana, 1999: 151). Metode ini dapat dijumpai dalam alQur'an yang sekaligus hal itu menjadi dasar bagi guru PAI dalam menelaahnya secara inheren. Allah SWT berfirman:

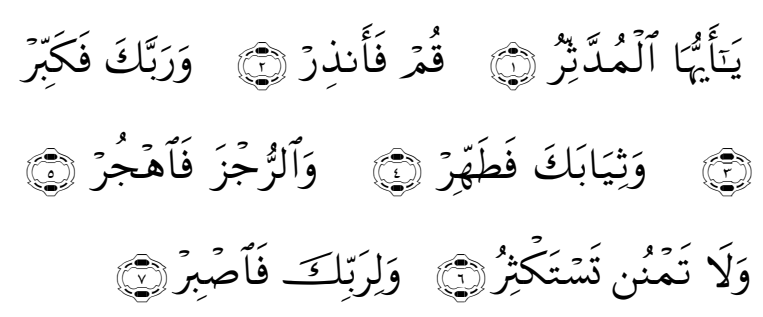

Artinya: "Hai orang yang berselimut. Bangunlah, lalu berilah peringatan! Dan Tuhanmu agungkanlah! Dan pakaianmu bersihkanlah. Dan perbuatan dosa tinggalkanlah. Dan janganlah kamu memberi (dengan maksud) memperoleh (balasan) yang lebih banyak. Dan untuk (memenuhi perintah) Tuhanmu, bersabarlah." (QS. Al-Muddatstsir, 74: 17).

Ayat di atas memerintahkan kepada Nabi Muhammad SAW; wahai yang berselimut, yakni Nabi Muhammad SAW, bangkitlah dengan sempurna dan 
giat, lalu berilah peringatan mereka yang lengah dan melupakan Allah (Shihab, 2012: 442). Kata yang menggambarkan makna metode resitasi dalam pembelajaran PAI dari ayat di atas adalah ya ayyuhal muddatstsir, qum fa anzir, artinya wahai orang yang berselimut, bagunlah dan berikanlah peringatan, dan tuhanmu agungkanlah, sampai akhir akhir ayat. Kata "qum" pada ayat di atas merupakan fi'il amar yang menggambarkan adanya perintah yang harus dikerjakan oleh orang yang berselimut (Nabi Muhammad SAW). Perintah tersebut apabila dilihat pada mafhum mukhalafah-nya merupakan tugas penting yang menuntut pada sebuah kewajiban untuk mengerjakannya. Hal ini kemudian mengilustrasikan adanya tugas yang harus diemban oleh Nabi Muhammad SAW untuk diberikan dan diselesaikan.

Di sini terdapat pemberi tugas yaitu Allah SWT yang berperan untuk memberikan tugas, yang dalam bahasa pendidikan dapat disebut dengan guru, kepada Nabi Muhammad SAW sebagai penerima tugas yang juga dapat disebut dengan orang menerima pelajaran atau peringatan yaitu peserta didik. Orang yang memberi tugas (peringatan) tersebut dalam ayat di atas adalah Allah SWT kepada Nabi Muhammad SAW. Kata almuddatstsir, menurut Quraish Shihab, terambil dari kata iddatsara. Kata ini apapun bentuknya tidak ditemukan dalam al-Qur'an kecuali sekali, yaitu pada ayat pertama surah ini. Iddatsara berarti mengenakan ditsar, yaitu sejenis kain yang diletakkan di atas baju yang dipakai dengan tujuan menghangatkan dan atau dipakai sewaktu berbaring tidur (selimut). Disepakati oleh ulama tafsir bahwa yang dimaksud dengan yang berselimut adalah Nabi Muhammad SAW (Shihab, 2012: 442).
Kata ini di sisi lain, tersirat pula dari kata ya ayyuhalmuddatstsir rasa kasih sayang serta "kedekatan" Tuhan kepada pribadi yang diseru itu. Karena salah satu cara yang digunakan oleh bahasa untuk menggambarkan hal tersebut adalah memanggil seseorang dengan keadaannya sewaktu ia dipanggil. Sahabat Nabi Muhammad SAW, Hudzaifah ra., ketika ditemui Oleh Nabi Muhammad SAW sedang tertidur pada malam perang Khandaq, beliau membangunkannya dengan menyerunya qum ya nauman (bangunlah wahai si penidur). Demikian juga ketika terjadi kesalahpamahaman antara Sayyidina Ali ibn Abi Thalib dan istri beliau, Fatimah ra., putri Rasulullah SAW sehingga Ali meninggalkan rumah dan tertidur di masjid sampai pakaian dan tubuhnya berlumuran tanah, Nabi membangunkannya dengan ucapan, qum ya $a b a$ turab (bangunlah wahai yang penuh dengan tanah). Ucapan-ucapan ini menggambarkan bahwa pengucapnya tidak marah bahkan nenyayangi dan merasa dekat dengan orang yang diseru itu. Contoh ini berlaku pula antara Allah SWT dan Nabi Muhammad SAW yang merasa takut, bahkan menghindar dari Jibril yang membawa pesan-pesan Tuhan kepadanya (Shihab, 2012: 443444). Maka bila makna ini dikomparasikan dengan metode pembelajaran PAI, tergambar jelas bahwa adanya guru yang memberikan tugas (Allah SWT) dan penerima tugas (Nabi Muhammad SAW). Pemberi tugas tersebut dapat disebut dengan guru yang harus memiliki sifat rasa kasih sayang serta dekat dengan penerima tugas yaitu peserta didik dalam pembelajaran. Antara guru dan peserta didik harus terjalin sifat kasih sayang agar pesan-pesan pembelajaran (materi) dapat memenuhi sasaran dengan baik. 
Setelah itu, terdapat tugas penting yang harus diberikan oleh seorang guru PAI kepada para peserta didiknya, dapat dilihat dari ayat berikutnya, yaitu qum $f a$ andzir, bangkitlah, lalu berilah peringatan. Menurut Qurasih Shihab, kata qum terambil dari kata qawama yang mempunyai banyak bentuk. Secara umum kata-kata yang dibentuk dari akar kata tersebut diartikan sebagai "melaksanakan sesuatu secara sempurna dalam berbagai seginya". Karena itu perintah di atas menuntut kebangkitan yang sempurna, penuh semangat, dan percaya diri sehingga yang diseru-dalam hal ini Nabi Muhammad SAW-harus membuka selimut, menyingsingkan lengan baju untuk berjuang menghadapi kaum musyrikin (Shihab, 2012: 444). Bila makna kata ini dikaitkan dengan metode resitasi menggambarkan bahwa para peserta didik dalam mengikut pembelajaran dengan metode ini haruslah memiliki jiwa kebangkitan yang sempurna, semangat dan percaya diri dalam menerima dan melaksanakan tugas materi pembelajaran yang diberikan oleh guru PAI.

Hal yang paling penting untuk diperhatikan dari ayat di atas adalah kata fa andzir, yang bermakna berilah peringatan. Kata andzir berbentuk fi'il $a m r$, kata perintah, yang mengandung adanya tugas penting untuk dikerjakan. Ulama berpendapat bahwa "pada dasarnya perintah di sini belum ditujukan secara khusus kepada siapa pun. Hal yang penting adalah melakukan peringatan, kepada siapa saja, terserah kepada Rasulullah SAW. Hal ini sama dengan perintah makan dan minum, baik yang ditemukan dalam al-Qur'an maupun ucapan seseorang yang mempersilakan tamunya untuk makan dan minum" (Shihab, 2012: 445). Bila hal ini dikomparasikan dengan metode resitasi dalam pembelajaran PAI, menggambarkan adanya tugas penting yang harus dikerjakan oleh peserta didik. Peserta didik pun harus melaksanakan tugas tersebut dengan baik hingga mencapai hasil yang maksimal sesuai tujuan pembelajaran.

Nabi Muhammad SAW sebagai seorang yang diberi tugas, sebagai peserta didik dalam pembelajaran, oleh Allah SWT—sebagai pendidik, memiliki hal-hal penting untuk dimiliki. Dan Tuhanmu, maka agungkanlah, karena memberi peringatan dapat mengakibatkan kebencian dan gangguan dari yang diperingati, ayat di atas melanjutkan bahwa dan bersamaan dengan itu hanya Tuhan Pemelihara dan Pendidik-mu saja-apa pun yang terjadi maka angungkanlah! Ayat ketiga dari surah ini sampai dengan ayat ketujuh, yang turun satu rangkaian dengan ayat pertama dan kedua, menurut Quraish Shihab, merupakan petunjuk Allah SWT dalam rangka pembinaan diri Nabi Muhammad SAW demi suksesnya tugastugas kenabian (Shihab, 2012: 446).

Di sini semakin jelas bahwa penggunaan metode resitasi menuntut para peserta didik harus memiliki kepribadian yang tergambar dari ayat ketiga hingga ketujuh dari ayat di atas. Suksesnya pelaksanaan tugas-tugas yang diberikan oleh guru, seorang peserta didik haruslah memahami dan mengamalkan beberapa pentunjuk penting yaitu; dan Tuhanmu, maka agungkanlah; dan pakaianmu, maka bersihkanlah; dan dosa, maka tinggankanlah; dan janganlah memberi (untuk) memeroleh yang lebih banyak; dan hanya kepada Tuhanmu saja maka bersabarlah (Shihab, 2012: 446-451).

Ayat ketiga sampai dengan ketujuh pada surat di atas bukanlah tugas yang harus dilaksanakan oleh Rasulullah SAW, akan tetapi petunjuk penting bagi Nabi SAW yang diberikan oleh Allah SWT dalam melaksanakan tugas dakwah 
pada umat manusia. Di sini menggambarkan bahwa seorang guru PAI saat menggunakan metode resitasi tersebut haruslah membina peserta didik dengan berbagai persyaratan di atas. Dalam pelaksanaan tugas tersebut peserta didik harus senantiasa memiliki sifat mengagungkan Tuhan; membersihkan pakaian; meninggalkan dosa; jangan memberi (untuk) memeroleh yang lebih banyak; dan bersabarlah hanya kepada Tuhan.

\section{SITUASI PENGGUNAAN}

Metode resitasi dalam pelajaran PAI diberikan karena dirasakan bahan pelajaran terlalu banyak, sementara waktu sedikit. Artinya, banyaknya bahan yang tersedia dengan waktu kurang seimbang. Agar bahan pelajaran selesai sesuai batas waktu yang di tentukan, maka metode resitasi inilah yang biasanya guru PAI gunakan untuk mengatasinya. Kegiatan interaksi belajar mengajar harus selalu ditingkatkan efektifitas dan efisiensinya. Dengan banyaknya kegiatan pendidikan di sekolah, dalam usaha meningkatkan mutu dan frekuensi isi pelajaran, maka sangat menyita waktu peserta didikuntuk melaksanakan kegiatan belajar mengajar tersebut.

Untuk mengatasi keadaan tersebut guru PAI perlu memberikan tugas- tugas di luar jam pelajaran. Disebabkan bila hanya menggunakan seluruh jam pelajaran yang ada untuk tiap mata pelajaran hal itu tidak akan mencukupi tuntutan luasnya pelajaran yang di haruskan, seperti yang di cantum dalam kurikulum. Dengan demikian perlu di berikan tugas- tugas, sebagai selingan untuk variasi teknik penyajian ataupun dapat berupa pekerjaan rumah.

Tugas semacam itu dapat dikerjakan di luar jam pelajaran, di rumah maupun sebelum pulang, sehingga dapat dikerjakan bersama temannya. Tugas dapat diberikan dalam bentuk daftar sejumlah pertanyaan mengenai mata pelajaran tertentu, atau satu perintah yang harus dibahas dengan diskusi atau perlu di cari uraianya pada buku pelajaran. Dapat juga berupa tugas tertulis atau tugas lisan yang lain, dapat ditugaskan untuk mengumpulkan sesuatu; membuat sesuatu, mengadakan observasi terhadap sesuatu dan bisa juga melakukan eksperimen. Hanya diharapkan bila guru telah memberikan tugas pada peserta didik, hari berikutnya harus dicek apakah sudah di kerjakan atau belum. Kemudian perlu di evaluasi, karena akan memberi motivasi belajar peserta didik. Tugas itu dapat juga berupa perintah, kemudian peserta didik mempelajari bersama teman atau sendiri dan menyusun laporan/resume.

Esok harinya laporan itu dibacakan di depan kelas dan didiskusikan dengan peserta didik seluruh kelas. Sistem tugas semacam ini disebut resitasi, ialah menyusun suatu laporan sebagai hasil dari apa yang telah di pelajari. Metode tugas belajar dan resitasi merangsang anak untuk aktif belajar baik secara individual maupun secara kelompok. Oleh karena itu tugas dapat diberikan secara individual, atau dapat pula secara kelompok. Metode resitasi ini dilakukan:

Pertama, apabila guru mengharapkan agar semua pengetahuan yang telah diterima anak lebih mantap. Kadang kala ada saja sebuah indikator pembelajaran belum maksimal dikuasai oleh peserta didik dan itulah saatnya metode resitasi dapat dipergunakan.

Kedua, untuk mengaktifkan anakanak mempelajari sendiri suatu masalah dengan membaca sendiri, mengerjakan soal-soal sendiri, mencoba sendiri. Metode resitasi ini dapat dipergunakan 
apabila guru PAI menginginkan peserta didiknya untuk dapat belajar mandiri. Peserta didik mengerjakan persoalan dan mempelajari pembelajaran PAI secara individu dengan kemampuan dirinya sendirinya.

Ketiga, agar anak-anak lebih rajin. Metode resitasi dapat dipergunakan untuk membuat kebiasaan peserta didik untuk lebih rajin dalam belajar. Belajar tidak hanya di ruang kelas saja, akan tetapi dapat pula dilakukan di mana saja, sehingga peserta didik dapat membiasakan diri rajin belajar.

Memberikan tugas-tugas kepada peserta didik berarti memberi kesempatan untuk mempraktekkan keterampilan yang baru saja mereka dapatkan dari guru disekolah, serta menghafal dan lebih memperdalam materi pelajaran. Peranan penugasan kepada peserta didik sangat penting dalam pengajaran, hal ini dijelaskan oleh I. L. Pasaribu, bahwa metode resitasi merupakan suatu aspek dari metodemetode mengajar. Karena tugas-tugas meninjau pelajaran baru, untuk menghafal pelajaran yang sudah diajarkan, untuk latihan-latihan, dengan tugas untuk mengumpulkkan bahan, untuk memecahkan suatu masalah dan seterusnya (Pasaribu, 1986: 108).

Penggunaan metode resitasi dalam pembelajaran dapat memperdalam pengertian peserta didik terhadap pelajaran yang telah diterima, melatih peserta didik ke arah belajar mandiri, dapat membagi waktu secara teratur, memanfaatkan waktu luang, melatih untuk menemukan sendiri cara-cara yang tepat untuk menyelesaikan tugas dan memperkaya pengalaman di sekolah melalau kegiatan di luar kelas (Wiryawan, 1990: 30).

\section{KELEBIHAN DAN KEKURANGAN METODE RESITASI Kelebihan Metode Resitasi}

Metode resitasi mempunyai kelebihan dan kelemahan dalam proses belajar mengajar. Adapun kelebihan metode resitasi adalah anak menjadi terbiasa mengisi waktu luangnya, memupuk rasa tanggung jawab, melatih anak berfikir kritis, tekun, giat dan rajin. Sedangkan kelemahan metode resitasi antara lain : tidak jarang pekerjaan yang ditugaskan itu diselesaikan dengan jalan meniru, karena perbedaan individual anak tugas diberikan secara umum mungkin beberapa orang diantaranya merasa sukar sedang yang lain merasa mudah menyelesaikan tugas itu dan apabila tugas sering diberikan maka ketenangan mental pada peserta didik terpengaruh (Alipandie, 1984: 92).

Belajar dengan metode resitasi, peserta didik akan terlatih dalam mempelajari suatu masalah dengan mengarahkan kemampuan sendiri yang pada gilirannya peserta didik akan terbiasa mengisi waktu luangnya di luar jam pelajaran di sekolah, baik di perpustakaan maupun di laboratorium.Kelebihan Metode ini adalah:

Pertama, lebih merangsang peserta didik dalam melakukan aktivitas belajar individual ataupun kelompok. Metode resitasi dalam pelaksanaan pembelajaran PAI dapat merangsang peserta didik untuk melakukan aktivitas pembelajarannya secara individu ataupun kelompok. Proses belajar seperti ini menjadikan peserta didik dapat bekerjasama dengan baik bersama kawan-kawan. Di samping itu juga membiasakan diri peserta didik untuk menyelesaikan persoalan yang dihadapi dalam pembelajaran PAI secara individu.

Kedua, dapat mengembangkan kemandirian peserta didik di luar 
pengawasan guru. Ketika peserta didik dapat belajar secara individu dan kelompok, maka akan melahirkan kemandirian tinggi dalam diri peserta didik. Penggunaan metode resitasi dalam pembelajaran PAI dapat mengarahkan peserta didik memiliki ketangguhan dan kompetisi yang dilahirkan dari kemandirian. Tak jarang peserta didik yang mengikuti pembelajaran PAI di kelas terkadang kurang mandiri dan percaya diri dengan dirinya sendiri. Dengan adanya metode resitasi hal itu dapat teratasi hingga muncul rasa percaya diri yang lahir dari kemandirian tersebut.

Ketiga, dapat membina tanggung jawab dan disiplin peserta didik. Penggunaan metode ini dalam pembelajaran PAI dapat membina tanggung jawab dan disiplin peserta didik. Materi yang dikerjakan dengan mandiri melalui tugas-tugas berdampak pada munculnya tanggung jawab dari diri peserta didik. Tanggung jawab tersebut muncul karena bila tugas yang dikerjakan tidak sesuai maka secara individu peserta didik tersebut harus bertanggung jawab. Peserta didik mengerjakan tugas-tugas yang diberikan melaksanakannya secara sendirian tanpa melibatkan orang lain dan guru.

Ketepatan waktu pengerjaan materi pembelajaran yang dilakukan oleh peserta didik dapat menjadikan dirinya disiplin. Disiplin ini bagian penting dalam menjadikan diri peserta didik sebuah karakter penting untuk dikembangkan. Tugas yang diberikan guru melalui metode resitasi dapat memupuk disiplin peserta didik dalam proses pembelajaran PAI di sekolah.

Keempat, dapat mengembangkan kreativitas peserta didik. Oleh karena metode resitasi merupakan pengerjaan tugas-tugas secara individu maka dituntut kreaativitas peserta didik secara mandiri. Peserta didik harus mengerjakan tugas dengan sendirian melalui pengoalahan pemikirannya sendiri. Bila sebuah pekerjaan dilakukan dengan sendiri maka tentu harus dapat diselesaikan dengan baik secara individu juga.

\section{Kelemahan Metode Resitasi}

Sementara itu, metode resitasi tak terlepas dari berbagai kekurangan yang melingkupinya. Kekurangan metode resitasi tersebut dalam pembelajaran PAI adalah:

Pertama, peserta didik sulit dikontrol mengenai pengerjaan tugas. Kontrol ini merupakan bagian penting dalam proses pembelajaran. Tugas yang diberikan kepada masing-masing individu peserta didik memungkinkan akan membuat Kontrol guru terhadap semua peserta didik sangat terbatas.

Kedua, khusunya untuk tugas kelompok, tidak jarang yang aktif mengerjakan dan menyelesaikan adalah anggota tertentu saja, sedangkan anggota lainnya tidak berpartisipasi dengan baik. Penyakit mengerjakan tugas dalam kelompok adalah adanya sebagian peserta didik yang aktif sementara yang lainnya pasif. Akhirnya peserta didik bekerja secara invidu karena yang lainnya tidak mau ambil pusing dengan tugas yang diberikan.

Ketiga, tidak mudah memberikan tugas yang sesuai dengan perbedaan individu peserta didik. Merinci tugastugas yang relevan dengan tiologi belajar peserta didik bukanlah persoalan mudah. Hal itu menuntut kehati-hartian seorang guru PAI untuk menjembatani hal tersebut. Tugas harus dibuat sebanyak peserta didik yang menuntut pada penelahaan guru terhadap materi PAI yang diajarkan dan pemahaman peserta didik terhadap tipologi belajar peserta didik. Barangkali hal penting untuk diperhatikan terkait 
dengan perbedaan tipologi peserta didik ini adalah tugas yang menuntut semua peserta didik untuk aktif dan diprediksi dapat dilakukan oleh semua peserta didik.

Keempat, sering memberikan tugas yang monoton dapat menimbulkan kebosanan peserta didik. Tugas yang monoton dapat membuat peserta didik kurang semangat dalam belajar karena tidak ada inovasi-inovasi baru yang dapat dipetik oleh peserta didik. Oleh karena itu seorang guru PAI haruslah dapat mengembangkan tugas-tugas yang bervariasi bentuk pelaksanaannya. Bila tugas yang diberikan monoton maka ketercapaian peserta didik terhadap materi pembelajaran akan jauh dari harapan sesungguhnya.

\section{DESAIN METODE RESITASI}

Seorang guru PAI yang mengajarkan bidang studi Pendidikan Agama Islam haruslah mengetahui langkah-langkah penggunaan metode resitasi dalam pengaajarannya. Langkah-langkah ini menjadi penting untuk mengusung pembelajaran PAI yang dilaksanakan dapat mencapai tujuan yang telah ditetapkan dengan maksimal. Langkahlangkah metode resitasi dalam pembelajaran PAI dapat dilihat pada tabel berikut:

\section{Gambar 1}

\section{Siklus Metode Resitasi dalam Pembelajaran Pendidikan Agama Islam}

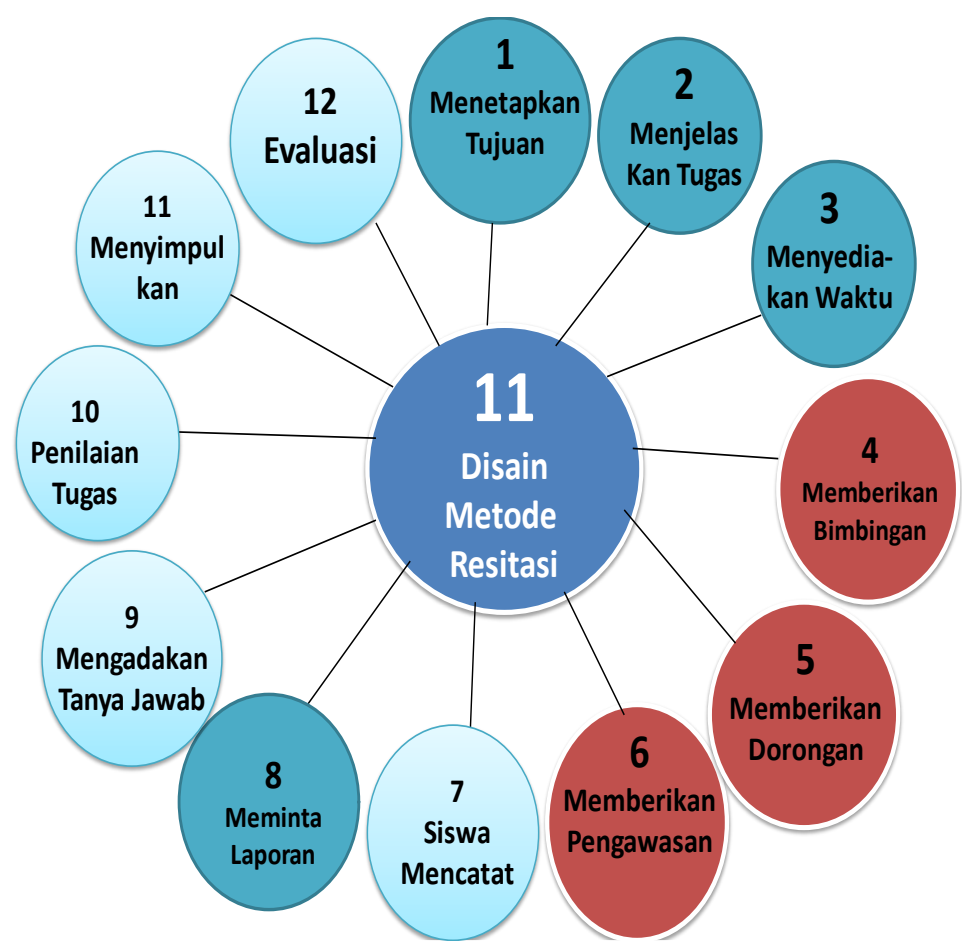

Sebelas langkah di atas secara umum terbagi pada tiga fase yang biasa terdapat dalam langkah-langkah metode pembelajaran PAI, yaitu fase pemberian tugas, pelaksaan tugas, dan pertanggungjawaban tugas. Sebelas langkah di atas masuk pada tiga kegiatan yang harus diperhatikan. Pertama, fase pemberian tugas, di dalamnya memuat langkah-langkah 
yaitu menetapkan tujuan, menjelaskan tugas, dan menyediakan waktu. Fase pemberian tugas ini merupakan langkah awal yang harus menjadi perhatian utama guru PAI. Kedua, pelaksanaan tugas. Kegiatan pelaksanaan tugas ini merupakan tahap inti dalam proses penggunaan metode resitasi. Pada kegiatan ini guru PAI harus menggunakan langkah-langkah penting yaitu memberikan bimbingan, memberikan dorongan, memberikan pengawasan, dan meminta peserta didik untuk mencatat hasil tugas. Ketiga, fase pertanggungjawaban tugas. Fase ini merupakan tahap akhir dari proses penggunaan metode resitasi dalam pembelajaran PAI. Fase pertanggungjawaban ini harus dikemas sedemikian rupa, sebab di sinilah kekuatan dari metode ini. Tanpa adanya pertanggungjawaban tugas maka tugas yang dikerjakan oleh peserta didik hanyalah tugas tinggal tugas seolah tak begitu berarti. Fase pertanggungjawaban ini dilakukan dengan langkah, yaitu meminta laporan, mengadakan tanya jawab, memberikan penilaian, kesimpulan, dan evaluasi. Kesebelas langkah tersebut akan dijelaskan satu persatu di bawah ini.

\section{Menetapkan Tujuan}

Lengkah pertama, menetapkan tujuan pembelajaran yang jelas. Tujuan pembelajaran PAI dengan metode resitasi ini harus dianalisis dengan baik dan seksama. Penetapan tujuan ini berpedoman pada indikator pembelajaran yang telah ditetapkan. Tujuan dalam metode resitasi bisa saja dapat dipecah dari indikator yang ada, bukan dari sub materi pelajaran yang diajarkan dalam materi PAI. Tujuan ini haruslah mengacu pada indikator pembelajaran PAI bukan pada hasrat dan keinginan guru PAI yang keluar dari indikator pembelajaran tersebut.

Keberhasilan metode resitasi, ukuran akhirnya adalah pada ketercapaian dari tujuan pembelajaran PAI yang telah ditetapkan tersebut. Oleh karen ini itu sebelum guru PAI melangkah lebih jauh maka hal utama yang harus dirancang adalah tujuan pembelajaran dengan metode resitasi tersebut. Hal ini menggambarkan tujuan tersebut sebagai pedoman utama untuk lengkah-langkah berikutnya dalam penggunaan metode resitasi.

Pada tahap ini guru PAI harus memperhatikan dan melakukan hal-hal penting yang menjadi panduan yaitu; (1) bertanya kepada peserta didik tentang materi yang sebelumnya dipelajari; (2) meminta satu atau dua orang peserta didik memberi komentar pembelajaran sebelumnya; (3) menyampaikan tujuan pembelajaran dengan metode tanya jawab; dan (4) menyampaikan indikator pembelajaran pada peserta didik dan menanyakan pemahaman awal mereka terhadap indikator pembelajaran yang telah disampaikan.

\section{Menjelaskan Tugas}

Langkah kedua, menjelaskan tugas yang diberikan dengan jelas. Tugas yang diberikan haruslah dapat dimengerti dengan jelas oleh peserta didik. Menurut Sudirman tugas yang diberikan oleh guru haruslah jelas dan terang hingga tidak ada keraguan dan kebingungan peserta didik untuk mengerjakannya (Sudirman, 1992: 145). Hal ini menggambarkan bahwa tugas yang akan dikerjakan oleh peserta didik harus diterangkan dengan jelas oleh guru PAI.

Penjelasan guru PAI tentang tugas tersebut tidaklah disebut menggunakan metode ceramah. Akan tetapi penjelasan di sini hanyalah satu langkah penting atau bagian dari metode resitasi. 
Penjelasan terhadap tugas yang diberikan mengacu pada prinsip-prinsip humanis dan demokratis pada peserta didik. Pada tahap ini bisa saja diberikan kesempatan pada peserta didik untuk bertanya apabila ada hal yang belum jelas.

Seperti yang telah dijelaskan sebelumnya, bahwa tugas yang diberikan guru PAI kepada peserta didik dianalisis dari indikator pembelajaran PAI yang telah ditetapkan sebelumnya. Tugas ini bisa saja pengembangan dari indikator pembelajaran PAI untuk memperkaya wawasan pengembangan pengetahuan peserta didik. Atau bisa saja langsung pada indikator yang ada karena memang dianggap hal itu membutuhkan tugas langsung karena cakupannya sangat luas dan membutuhkan kemampuan analisis. Pemberian tugas ini dapat saja dilakukan secara individu atau kelompok. Tugas yang dikerjakan berkelompok merupakan materi yang luas yang menuntut kerjasama dalam tim. Tugas yang dilakukan secara individu merupakan tugas yang menuntut analisis masing-masing dan cakupannya hanya pada satu proses penyelesaian saja. Tugas yang diberikan pada peserta didik juga dapat berupa hal yang sama dimana guru PAI menuntut peserta didik untuk melakukan analisis masing-masing. Tapi juga tugas tersebut dapat saja diberikan dengan hal yang berbeda antara satu orang atau kelompok dengan lainnya sebagai maksud untuk memperkaya pengetahuan peserta didik tentang indikator yang sedang dipelajari.

Di sinilah seorang guru PAI harus menjelaskan secara detail tugas demi tugas yang akan dikerjakan oleh para peserta didiknya. Prosedur pelaksanaan tugas harus dijelaskan secara gamblang oleh guru PAI hingga para peserta didik benar-benar dapat memahami alur dan prosedur tersebut. Berapa lama waktu yang dibutuhkan untuk menyelesaikan tugas tersebut harus ditetapkan oleh guru PAI agar peserta didik dapat memenej diri hingga tidak kebablasan menghabiskan waktu dalam pelaksanaannya.

\section{Menyediakan Waktu}

Langkah ketiga, menyediakan waktu yang cukup untuk menyelasaikan tugas. Waktu sangat penting dalam penggunaan metode resitasi pada saat pembelajaran berlangsung. Tak jarang peserta didik kadang terlena mengerjakan tugas tapi lupa bahwa waktu yang tersedia telah habis. Oleh karena itu guru PAI harus sering mengingatkan peserta didik tentang waktu ini saat pembelajaran PAI sedang berlangsung dengan menggunakan metode resitasi tersebut. Hal ini dapat dilakukan bila pelaksanaan tugas tersebut dilangsungkan di dalam kelas.

Namun bila tugas tersebut dilaksanakan di luar kelas, seperti di laboratorium, di perpustakaan, atau di ruang lainnya, maka guru PAI harus memberikan tenggang waktu selama 45 menit misalnya, sesuai dengan jam pelajaran yang tersedia. Penyediaan waktu ini juga dapat disesuaikan dengan tempat pelaksanaan tugas tersebut. Bila tugas itu dikerjakan pada hari yang berbeda dengan waktu pembelajaran, maka harus pula ditetapkan waktu tersebut, semisal satu hari, dua hari dan selanjutnya.

\section{Memberikan Bimbingan}

Langkah keempat, guru PAI memberikan bimbingan. Guru PAI memberikan bimbingan kepada seluruh peserta didik terutama peserta didik yang mengalami kesulitan belajar atau salah arah dalam mengerjakan tugas. 
Bimbingan dapat berarti, suatu usaha untuk melengkapi individu dengan pengetahuan, pengalaman, dan informasi tentang dirinya sendiri. Suatu cara pemberian pertolongan atau bantuan kepada individu untuk memahami dan mempergunakan secara efisien dan efektif segala kesempatan yang dimiliki untuk perkembangan pribadinya. Suatu proses pemberian bantuan atau pertolongan kepada individu dalam hal memahami diri sendiri, menghubungkan pemahaman tentang dirinya sendiri dengan lingkungan: memilih, menentukan dan menyusun rencana sesuai dengan konsep dirinya sendiri dan tuntutan dari lingkungan (Tohirin, 2007: 35).

Bimbingan yang dimaksud pada tahapan ini bukanlah bimbingan seperti dalam kagiatan bimbingan konseling di sekolah. Akan tetapi memberikan pertolongan kepada peserta didik yang memiliki kesulitan dan keterlambatan dalam memahami tugas yang diberikan. Guru PAI memberikan arahan dengan membimbing peserta didik agar dapat dengan baik melaksanakan tugas yang telah diberikan.

\section{Memberikan Dorongan}

Langkah kelima, guru PAI memberikan dorongan. Guru PAI memberikan dorongan kepada seluruh peserta didik terutama bagi peserta didik yang lambat atau kurang bergairah mengerjakan tugas. Pemberian dorongan ini oleh guru PAI tentu bila peserta didik dapat secara umum bertemu dengan peserta didik dalam lingkungan yang dapat dijangkau. Bila tugas dikerjakan di dalam kelas maka secara otomatis guru PAI dapat secara langsung memberikan dorongan itu kepada mereka yang kurang bergairah. Guru PAI dapat melihat dengan langsung siapa saja peserta didik yang kurang bergairah dalam melaksanakan tugas dan dapat pula secara langsung memberikan arahan.

Bila tugas dikerjakan di laboratorium, di perpustakaan, dan ruang lainnya, maka guru PAI harus pula mengontrol dengan berjalan ke tempat di mana tugas tersebut dikerjakan. Di sini dapat saja guru PAI memberikan dorongan kepada peserta didik yang tak bergairah dalam melaksanakan tugasnya dan mengarahkannya untuk memberikan jalan kepada peserta didik. Namun ada saja tugas yang diberikan guru PAI tersebut di luar apa yang telah disebutkan sebelumnya, misalnya di rumah atau di tempat lain. Maka dorongan itu dapat dilakukan oleh guru PAI dan tetap harus dilakukan melalui orang tua, dan pimpinan di mana tempat peserta didik tersebut mengerjakan tugas.

Maka dalam penggunaan metode resitasi saat pembelajaran PAI mengharuskan adanya kerjasama yang dibangun oleh guru PAI dengan berbagai pihak khususnya orang tua. Kerjasama yang dibangun harus berdasarkan pada peningkatkan kompetensi peserta didik dan ilmu pengetahuan mereka. Tanpa adanya kerjasama yang baik antara guru PAI dengan pihak-pihak terkait maka penggunaan metode resitasi dalam pembelajaran PAI kurang tercapai secara maksimal.

\section{Memberikan Pengawasan}

Langkah keenam, guru PAI memberikan pengawasan agar tugas dikerjakan secara mandiri. Teknik ini merupakan hal penting untuk diperhatikan oleh guru PAI dalam pembelajaran PAI. Pengawasan dari guru PAI sangat penting untuk membiasakan diri peserta didik belajar mandiri. Kemandirian menjadi bagian terpenting yang harus dikembangkan 
oleh guru PAI kepada peserta didik dan itu dapat dimulai dari pengawasan. Sebab terkadang peserta didik dalam mengerjakan tugas tersebut dibuatkan oleh orang lain atau malah dibantu oleh orang lain.

Pengawasan ini dapat dilakukan oleh guru PAI dengan melakukan kerja sama kepada berbagai pihak seperti yang telah dikemukakan sebelumnya. Pengawasan yang dapat dilakukan melalui kerjasama dengan orang tua, pimpinan laboratorium, pimpinan perpustakaan, atau lainnya bila tugas tersebut di tempat-tempat tersebut. Pengawasan ini sangat penting untuk mendidik karakter kejujuran dan kemandirian peserta didik dalam melaksanakan tugas apapun yang diberikan padanya.

\section{Menganjurkan Agar Peserta didik Mencatat yang Diperoleh}

Langkah ketujuh, guru PAI menganjurkan agar peserta didik mencatat apa yang diperoleh. Tentu setiap apa saja yang diperoleh dari setiap penelaahan pembelajaran maka peserta didik harus menuliskannya dalam kertas bukunya. Anjuran dari guru PAI untuk hal ini sangat dibutuhkan agar peserta didik dapat mencatat hingga memahami apa yang seharusnya diketahui oleh peserta didik berdasarkan tujuan pembelajaran. Catatan terhadap materi pembelajaran yang dibiasakan oleh peserta didik akan menjadikan dirinya orang yang akan mengawali kesuksesan untuk di masa yang akan datang. Sebab pencatatan apa yang ditemui dan dilihat dapat menjadi sebuah kumpulan tulisan yang kemudian dapat dikembangkan menjadi buku untuk dibaca umum oleh masyarakat.

Mencatat hasil dari tugas yang diberikan oleh guru PAI melalui metode ini menjadi bagian penting yang harus dilalui oleh peserta didik. Salah satu poin utama dalam metode ini adanya penulisan tugas di mana peserta didik harus menuliskan hasil dari tugas yang dikerjakan. Tanpa adanya penulisan tugas ini maka metode resitasi tidak akan berarti dan pembelajaran pun tidak akan sampai pada sasaran yang sesungguhnya. Maka hal yang harus diperhatikan oleh guru PAI pada tahapan ini adalah; (1) Guru PAI meminta peserta didik untuk menuliskan garis besar yang harus diselesaikan. (2) Guru PAI meminta peserta didik untuk menuliskan jawaban terhadap tugas yang diberikan. (3) Guru PAI meminta peserta didik untuk memperhatikan kembali apa yang telah dituliskan hingga mendekati pada kesempurnaan tugas.

\section{Meminta Laporan}

Langkah kedelapan, guru PAI meminta laporan peserta didik terhadap hasil tugas yang telah dikerjakan. Hasil tugas yang telah selesai dikerjakan oleh peserta didik diberikan kepada guru PAI dalam bentuk tulisan. Guru PAI meminta laporan tugas tersebut kepada semua untuk kemudian dipertanggungjawabkan oleh peserta didik di depan kelas. Bila tugas PAI tersebut dilaksanakan secara individual, maka laporannya pun harus diberikan oleh peserta didik secara individual. Bila tugas PAI tersebut dilaksanakan secara berkelompok maka laporan tugas itu harus dikumpulkan oleh peserta didik secara kelompok pula.

Permintaan laporan tugas ini oleh guru PAI kepada peserta didik harus dilakukan secara ketat. Secara ketat dimaksudkan adalah dengan memeriksa hasil tugas yang terkait dengan sistematika penulisan yang telah disepakati. Hal ini dilakukan dengan 
maksud agar tugas yang dikerjakan oleh peserta didik melalui metode resitasi tidaklah dianggap sepele oleh peserta didik. Tugas yang dikerjakan oleh peserta didik betul-betul mereka dikerjakan dengan serius untuk mencapai pemahaman maksimal terhadap materi tugas yang diberikan.

\section{Mengadakan Tanya Jawab}

Langkah kesembilan, guru PAI mengadakan tanya jawab di dalam kelas terkait dengan laporan tugas peserta didik. Setelah tugas dikumpulkan oleh peserta didik dan berada di tangan guru, maka teknik berikutnya yang harus dilakukan oleh guru adalah mengadakan tanya jawab seputar tugas yang telah dikerjakan oleh peserta didik. Tanya jawab ini diperlukan untuk memberikan pemahaman kepada peserta didik lain terkait dengan hasil tugas yang dilaporkan oleh peserta didik lainnya. Sebab bisa saja hasil tugas seorang peserta didik akan kemungkinan bisa berbeda dengan hasil tugas peserta didik lainnya walau dengan persoalan yang sama, apalagi dengan tema yang berbeda.

Proses tanya jawab dapat dimulai oleh guru dengan melihat pada tugas seorang peserta didik dan menanyakan kepadanya terlebih dahulu, lalu selanjutnya meminta komentar peserta didik lainnya terhadap hasil yang dikemukakan peserta didik yang memiliki tugas tersebut, dan demikian seterusnya. Di sini guru hanya pengatur lalu lintas jalannya tanya jawab saja, yang menjawab pertanyaan-pertanyaan dan komentar-komentar tersebut adalah peserta didik itu sendiri. Guru PAI menggali hasil-hasil yang diperoleh untuk diberikan pertanyaan pada peserta didik dan peserta didik lainnya memberikan komentar terhadap jawaban-jawaban tersebut. Bila guru
PAI telah merasa cukup bahwa peserta didik telah mengetahui maksud sesuai dengan indikator yang ada maka guru PAI dapat saja menghentikannya dan mengarahkan kepada persoalan lainnya.

\section{Menyimpulkan}

Langkah kesepuluh, guru PAI menyimpulkan hasil pembelajaran dari tugas yang telah dikerjakan. Setelah seluruh peserta didik memberikan laporannya dan telah melaksanakan tanya jawab maka langkah berikutnya adalah menyimpulkan hasil pembelajaran. kesimpulan hasil pembelajaran ini dikoordinir oleh guru PAI dan bersama peserta didik membuat kesimpulan. Peserta didik diharapkan dapat secara aktif memberikan kesimpulan atas bimbingan dari guru PAI.

Pada tahapan ini teknik yang harus dilakukan oleh guru PAI adalah; (1) Guru PAI bersama peserta didik membuat kesimpulan bersama terkait dengan tugas yang telah diselesaikan; (2) Guru PAI dapat meminta peserta didik untuk memberikan hasil yang dipahami terhadap tugas; (3) Guru PAI meminta satu atau dua orang peserta didik untuk memberikan kesimpulan terhadap tugas yang dikerjakan.

\section{Memberikan Penilaian}

Langkah kesebelas, guru PAI memberikan penilaian terhadap hasil tugas peserta didik. Dalam memberikan tugas kepada peserta didik, guru diharuskan memeriksa dan memberi nilai. Rostiyah mengemukakan bahwa dengan mengevaluasi tugas yang diberikan kepada peserta didik, akan memberi motivasi belajar peserta didik (Rostiyah, 1989: 113). Tugas yang telah dibuat oleh peserta didik harus diberikan penilaian oleh guru PAI. 
Penilaian ini harus disusun terlebih dahulu oleh guru PAI melalui indikatorindikator penilaian. Tentu indikator penilaian ini misalnya sistematika penulisan, ketepatan tujuan tugas, analisis tugas, dan lainnya.

Penilaian terhadap tugas ini bukan sekedar melihat-lihat tugas peserta didik dan memberikan komentar penilaian yang tak berdasar. Seorang guru PAI harus memiliki indikator yang tersusun dalam menilai apakah tugas yang telah dilaporkan oleh peserta didik baik atau sebaliknya. Indikator ini dianggap penting untuk memberikan keadilan penilaian diantara semua peserta didik sekaligus menghindari kekurangpercayaan peserta didik terhadap guru PAI. Penilaian yang adil akan menumbuhkan rasa kepercayaan peserta didik terhadap kemampuannya dan itu memang harus didasari pada indikator yang jelas yang diberikan dan ditetapkan oleh guru PAI.

\section{Mengadakan Evaluasi}

Langkah keduabelas, evaluasi penggunaan metode resitasi dalam pembelajaran PAI. Evaluasi penggunaan metode ini dituntut harus dilakukan oleh guru PAI dalam setiap akhir pembelajarannya. Evaluasi ini dapat dilakukan melalui pertanyaan kepada peserta didik apakah penggunaan metode resitasi yang dilakukan oleh guru dapat diterima dengan baik oleh peserta didik. Menanyakan juga kepada peserta didik tentang kelemahankelemahan dan kekurangan-kekurangan yang seharusnya diperbaiki. Hal lain terkait dengan evaluasi penggunaan metode ini dapat pula dilakukan melalui observasi saat berlangsungnya pembelajaran metode resitasi. Juga dapat dilakukan dengan melihat pada hasil pembelajaran yang dicapai oleh peserta didik. Tentu bila nilai mereka tinggi dapat disimpulkan bahwa penggunaan metode resitasi tersebut berhasil dan demikian sebaliknya. Keberhasilan metode ini dapat pula dilihat dari keaktifan peserta didik dalam proses pembelajaran PAI. Bila peserta didik kurang aktif dalam pembelajaran maka dapatlah dengan mudah ditebak bahwa proses pembelajaran dengan metode resitasi kurang berhasil.

\section{SIMPULAN}

Metode resitasi dalam pendidikan agama Islam adalah penyajian bahan pelajaran PAI dengan memberikan tugas tertentu sesuai dengan indikator pembelajaran oleh guru PAI kepada peserta didik, dilakukan di dalam dan di luar kelas dalam lingkup lingkungan sekolah dan hasilnya dapat dipertanggungjawabkan peserta didik untuk mencapai tujuan pembelajaran.

Pengertian metode resitasi dalam pembelajaran PAI ini mengandung lima komponen penting yaitu; Pertama, adanya penyajian bahan pelajaran PAI. Penyajian bahan pelajaran dimaknai bahwa guru PAI menyajikan bahanbahan pelajaran yang telah dirumuskan dalam indikator pembelajaran kepada peserta didik. Penyajian bahan-bahan pelajaran ini tentu dilakukan oleh guru PAI di dalam kelas di mana peserta didik mengikutinya tetap sesuai dengan jadwal pembelajaran. Di sini guru PAI harus dapat memberikan analisis terhadap karakteristik materi pelajaran PAI yang sesuai dengan indikator pembelajaran untuk dapat diajarkan dengan metode resitasi. Hal ini menggambarkan bahwa tugas yang diberikan kepada peserta didik tidaklah lepas dari suasana kelas dan guru PAI harus menyajikan materi PAI.

Kedua, adanya pemberian tugas dari guru PAI kepada peserta didik. 
Tugas yang diberikan guru PAI kepada peserta didik dianalisis dari indikator pembelajaran PAI yang telah ditetapkan sebelumnya. Tugas ini bisa saja pengembangan dari indikator pembelajaran PAI untuk memperkaya wawasan pengembangan pengetahuan peserta didik. Atau bisa saja langsung pada indikator yang ada karena memang dianggap hal itu membutuhkan tugas langsung karena cakupannya sangat luas dan membutuhkan kemampuan analisis. Pemberian tugas ini dapat saja dilakukan secara individu atau kelompok. Tugas yang dikerjakan berkelompok merupakan materi yang luas yang menuntut kerjasama dalam tim. Tugas yang dilakukan secara individu merupakan tugas yang menuntut analisis masing-masing dan cakupannya hanya pada satu proses penyelesaian saja. Tugas yang diberikan pada peserta didik juga dapat berupa hal yang sama dimana guru PAI menuntut peserta didik untuk melakukan analisis masing-masing. Tapi juga tugas tersebut dapat saja diberikan dengan hal yang berbeda antara satu orang atau kelompok dengan lainnya sebagai maksud untuk memperkaya pengetahuan peserta didik tentang indikator yang sedang dipelajari.

Ketiga, dilakukan di dalam di luar kelas dalam lingkup lingkungan sekolah. Hal terpenting untuk dipahami oleh guru PAI juga adalah bahwa metode resitasi dapat dilakukan di dalam kelas dan dan juga di luar kelas dan selama itu berada dalam lingkup sekolah. Pemahaman terhadap hal ini perlu dikemukakan untuk menjelaskan pengertian metode ini karena ada sebahagian pendapat bahwa metode resitasi dilaksanakan di luar jam belajar.

Keempat, hasil tugas dapat dipertanggungjawabkan peserta didik. Tugas yang telah selesai dikerjakan oleh peserta didik harus dipertanggung- jawabkan di dalam kelas. Pertanggungjawaban ini merupakan laporan yang harus dipresentasikan oleh para peserta didik kepada peserta didik lainnya di dalam kelas. Maka sebelum peserta didik membertanggungjawabkan, haruslah disusun laporan tersebut sedemikian rupa sesuai prosedur yang telah ditetapkan hingga pada saat presentasi dapat secara tepat dilakukan. Perlu ditegaskan di sini bahwa tugas yang dipertanggungjawabkan tersebut haruslah dipresentasikan tidak bisa hanya sekedar laporan saja. Hal ini dilakukan karena bila hanya laporan saja tanpa dipresentasikan maka peserta didik yang lainnya tidak akan mengetahui apa hasil yang ditemukan peserta didik lainnya dan wawasan pengetahuan peserta didik pun berkurang. Sementara tugas tersebut sesuai dengan indikator pembelajaran, maka secara otomatis tugas yang telah diselesaikan harus diketahui oleh semua peserta didik.

Kelima, adanya pencapaian tujuan pembelajaran. Semua tugas yang dilakukan oleh peserta didik haruslah mengarah para proses tercapainya tujuan pembelajaran yang telah ditetapkan. Maka disaat para peserta didik memberikan pertanggungjawaban haruslah diperhatikan oleh guru apakah tugas tersebut telah sesuai dengan tujuan yang diharapkan. Semua peserta didik dalam proses penyelesaian tugas harus memperhatikan tujuan pembelajaran yang akan dicapai. Pencapaian tujuan ini merupakan panduan para peserta didik dalam pelaksanaan tugas-tugasnya hingga mereka dapat memetik hasil baik untuk dipahami dan diamalkan.

Nabi Muhammad SAW sebagai seorang yang diberi tugas, sebagai peserta didik dalam pembelajaran, oleh Allah SWT—sebagai pendidik, memiliki hal-hal penting untuk dimiliki, yaitu; mengagungkan Tuhan; membersihkan 
pakaian; meninggalkan dosa; jangan memberi (untuk) memeroleh yang lebih banyak; dan bersabarlah hanya kepada Tuhan.

Metode resitasi ini dilakukan pada hal berikut; Pertama, apabila guru mengharapkan agar semua pengetahuan yang telah diterima anak lebih mantap. Kadang kala ada saja sebuah indikator pembelajaran belum maksimal dikuasai oleh peserta didik dan itulah saatnya metode resitasi dapat dipergunakan. Kedua, untuk mengaktifkan anak-anak mempelajari sendiri suatu masalah dengan membaca sendiri, mengerjakan soal-soal sendiri, mencoba sendiri. Metode resitasi ini dapat dipergunakan apabila guru PAI menginginkan peserta didiknya untuk dapat belajar mandiri. Peserta didik mengerjakan persoalan dan mempelajari pembelajaran PAI secara individu dengan kemampuan dirinya sendirinya. Ketiga, agar anakanak lebih rajin. Metode resitasi dapat dipergunakan untuk membuat kebiasaan peserta didik untuk lebih rajin dalam belajar. Belajar tidak hanya di ruang kelas saja, akan tetapi dapat pula dilakukan di mana saja, sehingga peserta didik dapat membiasakan diri rajin belajar.

Metode resitasi mempunyai kelebihan dan kelemahan dalam proses belajar mengajar. Adapun kelebihan metode resitasi adalah; Pertama, lebih merangsang peserta didik dalam melakukan aktivitas belajar individual ataupun kelompok. Metode resitasi dalam pelaksanaan pembelajaran PAI dapat merangsang peserta didik untuk melakukan aktivitas pembelajarannya secara individu ataupun kelompok. Proses belajar seperti ini menjadikan peserta didik dapat bekerjasama dengan baik bersama kawan-kawan. Di samping itu juga membiasakan diri peserta didik untuk menyelesaikan persoalan yang dihadapi dalam pembelajaran PAI secara individu. Kedua, dapat mengembangkan kemandirian peserta didik di luar pengawasan guru. Ketika peserta didik dapat belajar secara individu dan kelompok, maka akan melahirkan kemandirian tinggi dalam diri peserta didik. Penggunaan metode resitasi dalam pembelajaran PAI dapat mengarahkan peserta didik memiliki ketangguhan dan kompetisi yang dilahirkan dari kemandirian. Tak jarang peserta didik yang mengikuti pembelajaran PAI di kelas terkadang kurang mandiri dan percaya diri dengan dirinya sendiri. Dengan adanya metode resitasi hal itu dapat teratasi hingga muncul rasa percaya diri yang lahir dari kemandirian tersebut. Ketiga, dapat membina tanggung jawab dan disiplin peserta didik. Penggunaan metode ini dalam pembelajaran PAI dapat membina tanggung jawab dan disiplin peserta didik. Materi yang dikerjakan dengan mandiri melalui tugas-tugas berdampak pada munculnya tanggung jawab dari diri peserta didik. Tanggung jawab tersebut muncul karena bila tugas yang dikerjakan tidak sesuai maka secara individu peserta didik tersebut harus bertanggung jawab. Peserta didik mengerjakan tugas-tugas yang diberikan melaksanakannya secara sendirian tanpa melibatkan orang lain dan guru. Keempat, dapat mengembangkan kreativitas peserta didik. Oleh karena metode resitasi merupakan pengerjaan tugas-tugas secara individu maka dituntut kreaativitas peserta didik secara mandiri. Peserta didik harus mengerjakan tugas dengan sendirian melalui pengoalahan pemikirannya sendiri. Bila sebuah pekerjaan dilakukan dengan sendiri maka tentu harus dapat diselesaikan dengan baik secara individu juga.

Sementara itu, metode resitasi tak terlepas dari berbagai kekurangan yang melingkupinya. Kekurangan metode 
resitasi tersebut dalam pembelajaran PAI adalah: Pertama, peserta didik sulit dikontrol mengenai pengerjaan tugas. Kontrol ini merupakan bagian penting dalam proses pembelajaran. Tugas yang diberikan kepada masing-masing individu peserta didik memungkinkan akan membuat Kontrol guru terhadap semua peserta didik sangat terbatas. Kedua, khusunya untuk tugas kelompok, tidak jarang yang aktif mengerjakan dan menyelesaikan adalah anggota tertentu saja, sedangkan anggota lainnya tidak berpartisipasi dengan baik. Penyakit mengerjakan tugas dalam kelompok adalah adanya sebagian peserta didik yang aktif sementara yang lainnya pasif. Akhirnya peserta didik bekerja secara invidu karena yang lainnya tidak mau ambil pusing dengan tugas yang diberikan. Ketiga, tidak mudah memberikan tugas yang sesuai dengan perbedaan individu peserta didik. Merinci tugas-tugas yang relevan dengan tiologi belajar peserta didik bukanlah persoalan mudah. Hal itu menuntut kehati-hartian seorang guru PAI untuk menjembatani hal tersebut. Tugas harus dibuat sebanyak peserta didik yang menuntut pada penelahaan guru terhadap materi PAI yang diajarkan dan pemahaman peserta didik terhadap tipologi belajar peserta didik. Keempat, sering memberikan tugas yang monoton dapat menimbulkan kebosanan peserta didik. Tugas yang monoton dapat membuat peserta didik kurang semangat dalam belajar karena tidak ada inovasi-inovasi baru yang dapat dipetik oleh peserta didik. Oleh karena itu seorang guru PAI haruslah dapat mengembangkan tugas-tugas yang bervariasi bentuk pelaksanaannya. Bila tugas yang diberikan monoton maka ketercapaian peserta didik terhadap materi pembelajaran akan jauh dari harapan sesungguhnya.
Terdapat sebelas langkah terbagi pada tiga fase yang biasa dalam metode pembelajaran PAI, yaitu fase pemberian tugas, pelaksaan tugas, dan pertanggungjawaban tugas. Sebelas langkah di atas masuk pada tiga kegiatan yang harus diperhatikan. Pertama, fase pemberian tugas, di dalamnya memuat langkah-langkah yaitu menetapkan tujuan, menjelaskan tugas, dan menyediakan waktu. Fase pemberian tugas ini merupakan langkah awal yang harus menjadi perhatian utama guru PAI. Kedua, pelaksanaan tugas. Kegiatan pelaksanaan tugas ini merupakan tahap inti dalam proses penggunaan metode resitasi. Pada kegiatan ini guru PAI harus menggunakan langkah-langkah penting yaitu memberikan bimbingan, memberikan dorongan, memberikan pengawasan, dan meminta peserta didik untuk mencatat hasil tugas. Ketiga, fase pertanggungjawaban tugas. Fase ini merupakan tahap akhir dari proses penggunaan metode resitasi dalam pembelajaran PAI. Fase pertanggungjawaban ini harus dikemas sedemikian rupa, sebab di sinilah kekuatan dari metode ini. Tanpa adanya pertanggungjawaban tugas maka tugas yang dikerjakan oleh peserta didik hanyalah tugas tinggal tugas seolah tak begitu berarti. Fase pertanggungjawaban ini dilakukan dengan langkah, yaitu meminta laporan, mengadakan tanya jawab, memberikan penilaian, kesimpulan, dan evaluasi.

\section{DAFTAR RUJUKAN}

Alipandie, Imansyah. 1984. Didaktik Metodik Pendidikan. Surabaya: Penerbit Usaha Nasional.

Harmawati. 1993. Pengaruh Pemberian Tugas Secara Terstruktur Terhadap 
Kemampuan Menyelesaikan SoalSoal. Jakarta: Bumi Aksara. cet. 1

I.L. Pasaribu. 1986. Didaktik Metodik. Bandung: Tarsito.

Mulyani. S dan Johar Permana. 1999. Strategi Belajar Mengajar. Jakarta: Departemen Pendidikan dan Kebudayaan Direktorat Jenderal Pendidikan Tinggi.

Rostiyah, N.K., 1989. Strategi Belajar Mengajar, Jakarta: Bina Aksara.

Sardiman A.M., 1987. Interaksi dan Motivasi Belajar Mengajar Pedoman Bagi Guru dan Calon Guru, Jakarta: Rajawali Press.

Shihab, Quraish. 2012. Tafsir al-Mishbah; Pesan, Kesan dan Keserasian alQur'an Volume 14, Jakarta: Lentera Hati. cet. ke -5
Slameto. 1991. Proses Belajar Mengajar dalam Sistem Kredit (SKS). Jakarta: Bumi Aksara. cet. 1

Sudirman. 1992. Ilmu Pendidikan. Bandung: Bina Aksara.

Sudjana, Nana. 1989. Dasar-Dasar Proses Belajar Mengajar. Bandung: Sinar Baru al-Gesindo. cet. 2

Syah, Darwyan, et. al., Perencanaan Sistem Pengajaran Pendidikan Agama Islam, Jakarta: Faza Media, 2006, cet. 1

Tohirin. 2007. Bimbingan dan Konseling di Sekolah dan Madrasah. Bandung: Remaja Rosdakarya.

Wiryawan, Sri Anitah. 1990. Strategi Belajar Mengajar. Jakarta: Universitas Terbuka. 